\title{
Effectiveness of ATP bioluminescence to assess hospital cleaning: a review
}

\author{
N. NANTE ${ }^{1}$, E. CERIALE ${ }^{2}$, G. MESSINA ${ }^{1}$, D. LENZI ${ }^{3}$, P. MANZI ${ }^{3}$ \\ ${ }^{1}$ Department of Molecular and Developmental Medicine, Laboratory of Environmental Hygiene, University of Siena, Italy; \\ ${ }^{2}$ Post-Graduate School in Public Health, University of Siena, Italy; ${ }^{3}$ Teaching Hospital "Le Scotte", Hospital Direction, Siena, Italy
}

\section{Keywords}

ATP Bioluminescence $\bullet$ Hospital Surfaces $•$ Healthcare-Associated Infections

\section{Summary}

Introduction. Contamination of hospital surfaces plays an important role in the transmission of several healthcare-associated microorganisms, therefore methods for evaluating hospital surfaces' cleaning gain particular importance. Among these, there are visual inspection, quantitative microbiology, fluorescent markers and adenosine triphosphate (ATP) bioluminescence. The latter seems to provide interesting features, detecting the presence of ATP on surface (as Relative Light Units, RLU), a proxy of organic matter and microbial contamination. Several studies have investigated the effectiveness of this technology; with this research, we aim to summarize the most significant results.

Methods. A systematic review was conducted. The keywords (namely, "ATP", "bioluminescence", "hospital" and "surfaces") were searched in PubMed/MEDLINE and Scopus databases, in

\section{Introduction}

Healthcare-associated infections (HAIs) represent an important and widespread cause of morbidity and mortality among patients. Over the past decades, various scientific evidences have accumulated, indicating that contamination of hospital surfaces plays an important role in the transmission and diffusion of several healthcareassociated microorganisms $[1,2]$. In particular, the hospital environment contributes to the transmission of several nosocomial pathogens, such as Clostridium difficile, methicillin-resistant Staphylococcus aureus (MRSA) and vancomycin-resistant Enterococcus (VRE) [2, 3]. These bacteria could survive in this setting for a variable period, from hours to days and, in some cases, even months, and could contaminate the surfaces or the medical devices [4]. Consequently, pathogens could infect patients or contaminate the hands of healthcare staff and, then, patients [2].

Within this perspective, methods to assess hospital environments cleaning can be considered an integral part of infections prevention and control programs. Among these, the most known and used are: visual inspection, microbial methods, fluorescent markers and adenosine triphosphate (ATP) bioluminescence. The latter measures the presence of ATP on surfaces. The ATP bioluminescence consists in a swab, used to sample a standard- order to find relevant data, from January 2000 to October 2014. After the selection, we globally considered 27 articles.

Results. Most of the studies were conducted in United Kingdom and in USA. Different threshold RLU benchmark values were identified by analyzed studies. Fourteen of these researches compared the ATP bioluminescence with microbiological methods, 11 identified a significant correlation between the two methods, although poor or not complete for 5.

Discussion. ATP bioluminescence is not a standardized methodology: each tool has different benchmark values, not always clearly defined. At the moment, we can say that the technique could be used to assess, in real time, hospital surfaces where cleanliness is required, but not sterility.

ized area, which, subsequently, is placed in a tool that uses the firefly enzyme "luciferase" to catalyze the conversion of ATP in Adenosine Monophosphate (AMP): this reaction results into an emission of light which is detected by the bioluminometer and quantified in Relative Light Unit (RLU). The presence of ATP on surface, obviously, is a proxy of organic matter and, consequently, of microbial contamination. This method has been used in food industries since over 30 years. Its use in the health care environment is growing, but it is still controversial, in that different tools consider different threshold values, and, therefore, this technique seems not to be standardized.

Several studies investigated the effectiveness and also evaluated the practical application of this technique in this setting. The aim of this study was to qualitatively synthesize and discuss the most significant results and implications of the applications of ATP bioluminescence in healthcare settings, reviewing the most recent scholarly literature.

\section{Methods}

We conducted a systematic review according to the "Preferred Reporting Items for Systematic Reviews and Meta-analyses" (PRISMA) guidelines [5]. The search 
Tab. I. Search strategy utilized in the current review.

\begin{tabular}{|l|l|}
\hline Search strategy item & Details \\
\hline Keywords & $\begin{array}{l}\text { Adenosine triphosphate, ATP, bioluminescence, bioluminometer, } \\
\text { surfaces, hospital }\end{array}$ \\
\hline Databases & PubMed/MEDLINE, Scopus \\
\hline Inclusion criteria & $\begin{array}{l}\text { Studies investigating the applications and effectiveness of ATP } \\
\text { bioluminescence } \\
\text { Studies conducted in healthcare settings }\end{array}$ \\
\hline Exclusion criteria & $\begin{array}{l}\text { Studies not carried out in healthcare settings } \\
\text { Studies lacking sufficient details } \\
\text { Studies not pertinent with the aim of this review } \\
\text { Study design: Overview/review articles }\end{array}$ \\
\hline Time filter & \begin{tabular}{l} 
January 2000-October 2014 \\
\hline Language filter
\end{tabular} \\
\hline Target journals & $\begin{array}{l}\text { Only articles written in English } \\
\text { Infection Control; Healthcare Infection; Infection control and } \\
\text { hospital epidemiology: the official journal of the Society of } \\
\text { Hospital Epidemiologists of America; International journal of } \\
\text { hygiene and environmental health; Journal of Infection Control; } \\
\text { Journal of Occupational and Environmental Hygiene }\end{array}$ \\
\hline
\end{tabular}

strategy consisted in a string of keywords such as ATP, bioluminescence, bioluminometer, hospital, healthcare setting, surfaces, connected by proper Boolean operators. For this scope, the keywords were searched in PubMed/MEDLINE and Scopus databases, in order to find relevant data. Time filter was applied and only articles from January 2000 to October 2014 were considered. Only articles written in English or for which an English translated text was available were included. Using Scopus we searched the keywords, selecting the option "all fields", whilst for PubMed/MEDLINE medical subject headings (MeSH) terms were used. All the searches as well as the screening were made by two researches EC and GM independently. Any disagreement was discussed until consensus was reached.

We included all types of studies, except: i) not peerreviewed scholarly articles; ii) overview/review articles, which were excluded but scanned for including further potentially relevant studies, iii) articles not written in English language, iv) all laboratory studies, not conducted in health care settings, and v) articles lacking sufficient details or not pertinent with the aim of our review. Further, selected target journals were hand-searched for increasing the chance of getting relevant articles. For ensuring a high-quality of the included studies, we did not search in the grey literature.

Table I reports our search strategy.

From each included study, we collected information about: i) the surname of the first author of the article and the year of publication; ii) the country where the research was carried out, iii) the setting in which the investigation was performed; iv) the samples used in the investigation; v) the RLU benchmark value discerning between clean and dirty surfaces (when investigated and reported), vi) the type of bioluminometers used, and vii) whether an eventual correlation between bioluminescence and microbiological methods existed (in terms of correlation coefficients, such as Pearson's coefficient, Spearman's rank coefficient, concordance $x$ coefficient or $\mathrm{R}^{2}$ ). The effect size of the correlation coefficient, when reported, was interpreted using the following rule of thumb: very high positive (or negative) if ranging from 0.90 to 1.00 (or ranging from -0.90 to -1.00 ): high positive (or negative) if ranging from 0.70 to 0.90 (or ranging from -0.70 to -0.90), moderate positive (or negative) if ranging from 0.50 to 0.70 (or ranging from -0.50 to -0.70 ), low/poor positive (or negative) if ranging from 0.30 to 0.50 (or ranging from -0.30 to -0.50$)$, and little/no correlation if ranging from 0.00 to 0.30 (or ranging from 0.00 to $-0.30)$. In the case the exact correlation coefficient was not indicated, we reported whether the correlation was statistically significant or not, on the basis of the p-value. Data extraction was carried out by two reviewers independently. In case of discrepancy, any disagreement was solved by discussion until consensus was reached or a third reviewer was involved.

\section{Results}

Using PubMed/MEDLINE we found 19 studies, 4 of which were judged not relevant for our investigation and one was a review, examining 12 papers, already found by our research. The final number of studies considered using PubMed/MEDLINE was 14. Therefore, in Scopus we found 315 papers, and only 27 were useful for the review. As such, the final number of studied included in the review was 27 (Fig. 1).

Concerning the data extracted, all studies were conducted in health care settings. Most of them were carried out in United Kingdom (UK) (10/27) [615]; 9 of them were performed in USA [16-24], 1 in Italy [25], Turkey [26], Japan [27], Chile [28], Canada [3], Norway [29], Australia [30] and Brazil [31]. Eleven researches monitored the surfaces after cleaning $[3,7,9-11,15,19,20,25,27,31]$, one before [23], 13 both pre and post cleaning [6, 8, 12-14, 16-18, 22, 24, 28$30]$ and in the remaining two studies this information 
Fig. 1. Preferred Reporting Items for Systematic Reviews and Meta-analyses (PRISMA) flowchart - Studies selection.

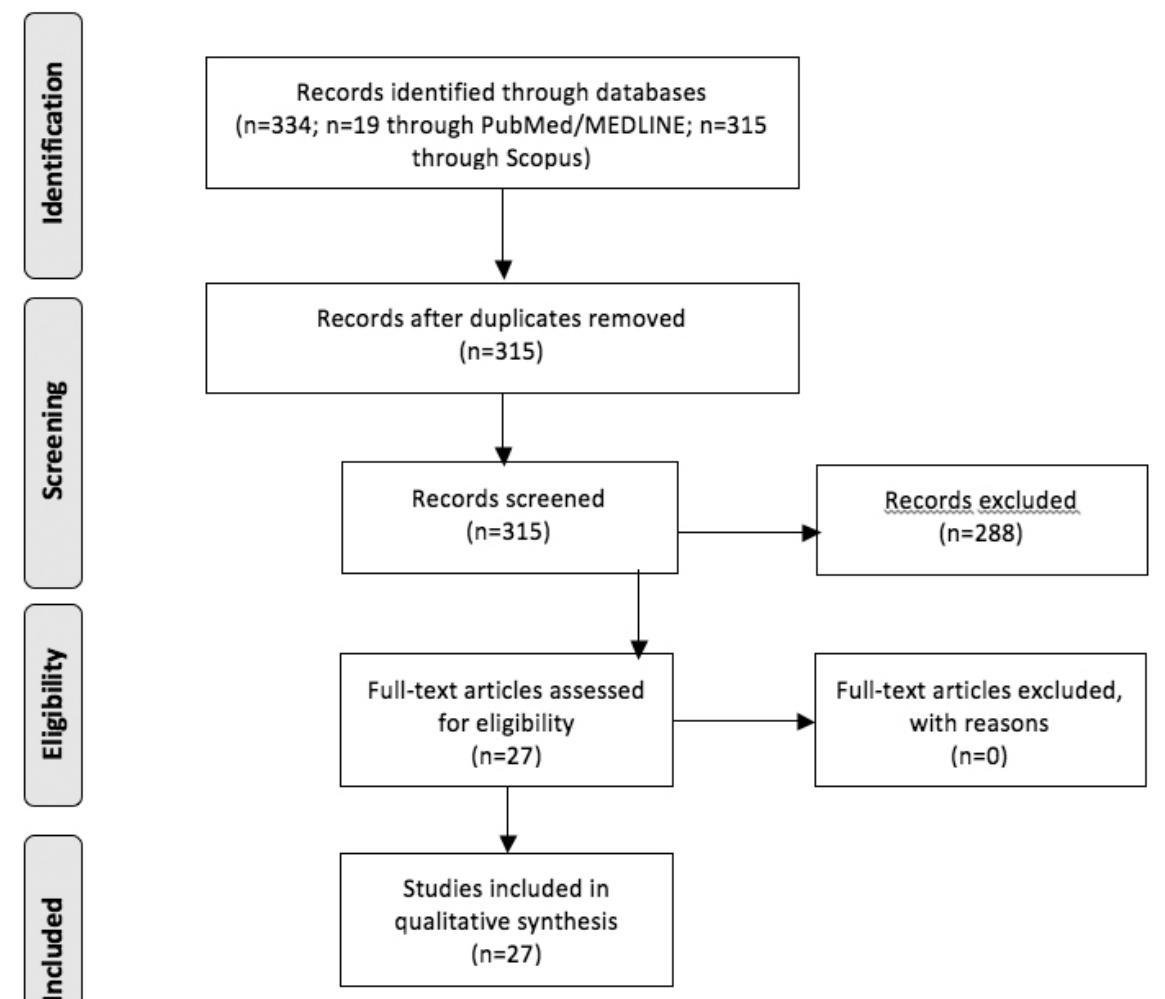

was not reported $[21,26]$. Twenty-three studies $(85.2 \%)$ identified a RLU benchmark value, discerning between clean and dirty surfaces. This value corresponded to 250 for 10 studies $[6,10,12,13,16-1821,23,24]$, to 500 for 7 researches $[8,9,11,12,14,29,31]$, to 100 for 4 studies [7, 15, 25, 29], to 300 for 2 studies [15, 19]; 127 [27], 1000 [3] and to 45 [20] for one study, respectively. Moore et al. [12] identified two threshold values: 250 and 500 RLU. Andersen et al. [29] used two different tools and, so, considered two different values: 500 RLU for ATP Biotrace Cleantrace system and 100 for Hygiena System. Another paper considered as cutoff 100 RLU for several patient rooms surfaces and 300 RLU for floors [15]. Details about RLU threshold values for each type of bioluminometers are shown in Figure 2. Figure 3 shows the benchmark values according to geographical provenance of studies.

Fourteen papers $(51.8 \%)$ [8, 10, 11, 13, 15, 17, 18, 22-27, 31] compared the effectiveness of ATP bioluminescence to assess hospital surfaces' cleaning with microbiological methods; in particular, these studies evaluated the correlation between RLU and Aerobic Colony Counts (ACC). Three of these studies have shown no correlation between the two compared methodologies [18, 22 31], whilst the remaining 11 have highlighted a correlation $[8,10,11,13,15,17,23-27]$, although it is poor/ moderate according to 4 studies $[15,17,25,27]$ and one found only a pre-cleaning correlation [24].

\section{Discussion}

Contamination of hospital surfaces plays an important role in the transmission of several healthcare-associated microorganisms. In this perspective, methods for evaluating hospital surfaces' cleaning gain importance. Each of these methods show advantages and disadvantages, and directives indicating the most appropriate method to use in different health care settings do not exist. The ATP bioluminescence seems to provide interesting perspectives, detecting the presence of ATP on surfaces (as Relative Light Units, RLU), a proxy of organic matter and microbial contamination. The present review showed the ATP bioluminescence is not a standardized method for assessing cleanliness; each tool had different benchmark values, ranging from 45 RLU to 1000 RLU. The most used values were 250 and 500 RLU. It is also interesting to note that for the same brand of bioluminometer different threshold values were considered.

The country where the studies were conducted may have influenced the choice of the RLU cutoff values, for example in the U.S. the most often used value corresponded to 500 RLU. The tool used in most studies was $3 \mathrm{M}$ Clean-Trace ATP System, following by Hygiena system and Biotrace Cleantrace System.

These differences among the benchmark values make difficult the comparisons between measurements carried out with different tools [15]. 
Tab. II. General features of the studies.

\begin{tabular}{|c|c|c|c|c|c|c|}
\hline Author/year & Country & Setting & Sample & $\begin{array}{c}\text { RLU } \\
\text { benchmark }\end{array}$ & $\begin{array}{c}\text { Correlation RLU/ } \\
\text { CFU }\end{array}$ & Brand bioluminometer \\
\hline Ali et al., 2012 [6] & UK & Hospital & $\begin{array}{l}60 \text { samples pre and } \\
60 \text { post cleaning }\end{array}$ & 250 & Not investigated & Not reported \\
\hline $\begin{array}{l}\text { Amin et al., } 2014 \\
\text { [16] }\end{array}$ & U.S. & $\begin{array}{c}\text { Clinic } \\
\text { ophtalmology } \\
\text { ward }\end{array}$ & $\begin{array}{l}396 \text { samples pre and } \\
396 \text { post cleaning }\end{array}$ & 250 & Not investigated & $\begin{array}{c}\text { 3M Clean-Trace ATP } \\
\text { System }\end{array}$ \\
\hline \begin{tabular}{|l|}
$\begin{array}{l}\text { Amodio et al., } 2013 \\
\text { [25] }\end{array}$ \\
\end{tabular} & Italy & Teaching hospital & $\begin{array}{l}193 \text { surfaces } \\
\text { postcleaning }\end{array}$ & 100 & Poor (R2=0.29) & $\begin{array}{c}\text { Luminocontrol II (PBI } \\
\text { internarnational, Milano) }\end{array}$ \\
\hline $\begin{array}{l}\text { Andersen et al., } \\
2008 \text { [29] }\end{array}$ & Norway & Teaching hospital & $\begin{array}{l}96 \text { samples pre and } \\
96 \text { post cleaning }\end{array}$ & 100,500 & Not investigated & $\begin{array}{l}\text { ATP Biotrace Clean-Trace } \\
\text { system; Hygiena System }\end{array}$ \\
\hline $\begin{array}{l}\text { Anderson et al., } \\
2011 \text { [7] }\end{array}$ & UK & $\begin{array}{c}\text { Hospital surgical } \\
\text { ward }\end{array}$ & $\begin{array}{l}44 \text { samples post- } \\
\text { cleaning }\end{array}$ & 100 & Not investigated & $\begin{array}{c}\text { SystemSure Plus system } \\
\text { (Hygiena Int. Ltd) }\end{array}$ \\
\hline \begin{tabular}{|l} 
Aycicek et al., 2015 \\
[26]
\end{tabular} & Turkey & Hospital kitchen & $\begin{array}{l}280 \text { from } 14 \\
\text { surfaces }\end{array}$ & Not reported & $\begin{array}{l}\text { Significant } \\
(x=0.249)\end{array}$ & Pd-10 kikkoman Co, Japan \\
\hline $\begin{array}{l}\text { Boyce et al., } 2009 \\
\text { [17] }\end{array}$ & U.S. & Teaching hospital & $\begin{array}{l}510 \text { samples pre and } \\
503 \text { post cleaning }\end{array}$ & 250 & $\begin{array}{l}\text { From poor to } \\
\text { moderate (r from } \\
0.356 \text { to 0.649) }\end{array}$ & $\begin{array}{c}\text { 3M Clean-Trace ATP } \\
\text { System }\end{array}$ \\
\hline $\begin{array}{l}\text { Boyce et al., } 2011 \\
\text { [18] }\end{array}$ & U.S. & Teaching hospital & $\begin{array}{c}500 \text { samples pre and } \\
500 \text { post cleaning }\end{array}$ & 250 & Not significant & $\begin{array}{c}\text { 3M Clean-Trace ATP } \\
\text { System }\end{array}$ \\
\hline $\begin{array}{l}\text { Branch-Elliman et } \\
\text { al., 2014 [19] }\end{array}$ & U.S. & Hospital & $\begin{array}{l}820 \text { samples post } \\
\text { clearing }\end{array}$ & 300 & Not investigated & $\begin{array}{l}\text { 3M Clean-Trace NG } \\
\text { Luminometer }\end{array}$ \\
\hline $\begin{array}{l}\text { Cooper et al., } 2007 \\
\text { [8] }\end{array}$ & UK & 4 hospital & $\begin{array}{l}552 \text { samples pre and } \\
547 \text { post cleaning }\end{array}$ & 500 & Significant & $\begin{array}{c}\text { Biotrace Cleantrace } \\
\text { system }\end{array}$ \\
\hline \begin{tabular}{|l|}
$\begin{array}{l}\text { Ferreira et al., } 2011 \\
\text { [31] }\end{array}$ \\
\end{tabular} & Brazil & Hospital & $\begin{array}{c}100 \text { samples post } \\
\text { clearing }\end{array}$ & 500 & Not significant & $\begin{array}{c}\text { 3M Clean-Trace ATP } \\
\text { System }\end{array}$ \\
\hline $\begin{array}{l}\text { Gillespie et al., } 2012 \\
\text { [30] }\end{array}$ & Australia & Hospital & $\begin{array}{l}50 \text { samples pre and } \\
50 \text { post cleaning }\end{array}$ & Not reported & Not investigated & Not reported \\
\hline $\begin{array}{l}\text { Gold et al., } 2013 \\
\text { [20] }\end{array}$ & U.S. & $\begin{array}{c}\text { Intensive Care } \\
\text { Unit (ICU) }\end{array}$ & $\begin{array}{c}\text { Postcleaning. } \\
\text { Number of surfaces } \\
\text { not specified }\end{array}$ & 45 & Not investigated & $\begin{array}{c}\text { Ruholf ATO Complete } \\
\text { contamination Monitoring } \\
\text { System }\end{array}$ \\
\hline $\begin{array}{l}\text { Cordon et al., } \\
\text { 2014[3] }\end{array}$ & Canada & Teaching hospital & $\begin{array}{l}15 \text { HTOs in } 36 \\
\text { patients rooms } \\
\text { (first day) and in } \\
37 \text { patients room } \\
\text { (second day) }\end{array}$ & 1000 & Not investigated & Not reported \\
\hline $\begin{array}{l}\text { Griffith et al., } 2008 \\
\text { [9] }\end{array}$ & UK & Hospital & $\begin{array}{c}31 \text { sites } \\
\text { postcleaning }\end{array}$ & 500 & Not reported & $\begin{array}{c}\text { Biotrace Clean-Trace } \\
\text { system }\end{array}$ \\
\hline $\begin{array}{l}\text { Havill et al., } 2011 \\
\text { [21] }\end{array}$ & U.S. & Teaching hospital & $\begin{array}{l}300 \text { samples from } \\
101 \text { rolling blood } \\
\text { pressure unit }\end{array}$ & 250 & Not investigated & $\begin{array}{c}\text { 3M Clean-Trace ATP } \\
\text { System }\end{array}$ \\
\hline \begin{tabular}{|l|} 
Lewis et al., 2008 \\
[10]
\end{tabular} & UK & Teaching hospital & $\begin{array}{l}180 \text { samples post } \\
\text { cleaning }\end{array}$ & 250 & Significant & $\begin{array}{c}\text { Biotrace International, Ltd, } \\
\text { Brigend, UK }\end{array}$ \\
\hline \begin{tabular}{|l|} 
Luick et al., 2013 \\
[22]
\end{tabular} & U.S. & Teaching hospital & $\begin{array}{l}250 \text { surfaces pre } \\
\text { and post cleaning }\end{array}$ & Not reported & Not significant & Accupoint HC (Neogen) \\
\hline $\begin{array}{l}\text { Malik et al., } 2003 \\
\text { [11] }\end{array}$ & UK & 4 hospitals & $\begin{array}{l}\text { non specified the } \\
\text { samples number. } \\
\text { Sampling done } \\
\text { postcleaning }\end{array}$ & 500 & Significant & $\begin{array}{c}\text { Biotrace Cleantrace } \\
\text { system }\end{array}$ \\
\hline $\begin{array}{l}\text { Mulvey et al., } 2011 \\
\text { [13] }\end{array}$ & UK & Teaching hospital & $\begin{array}{l}90 \text { samples pre and } \\
\text { post cleaning }\end{array}$ & 250 & Significant & Hygiena system \\
\hline $\begin{array}{l}\text { Moore et al., } 2010 \\
\text { [12] }\end{array}$ & UK & Teaching hospital & $\begin{array}{l}90 \text { samples pre and } \\
90 \text { post cleaning }\end{array}$ & 250,500 & Not investigated & $\begin{array}{c}\text { 3M Clean-Trace Clinical } \\
\text { Hygiene Monitoring } \\
\text { System }\end{array}$ \\
\hline \begin{tabular}{|l|} 
Sherlock et al., \\
2009 [14] \\
\end{tabular} & UK & $\begin{array}{c}\text { Two hospital } \\
\text { wards }\end{array}$ & $\begin{array}{l}120 \text { sample pre and } \\
120 \text { post cleaning }\end{array}$ & 500 & Not investigated & $\begin{array}{c}\text { 3M International Ltd, } \\
\text { Brigend, UK }\end{array}$ \\
\hline $\begin{array}{l}\text { Smith et al., } 2013 \\
\text { [23] }\end{array}$ & U.S. & Hospital & $\begin{array}{c}10 \text { samples in } 10 \\
\text { rooms pre and post- } \\
\text { cleaning }\end{array}$ & 250 & $\begin{array}{l}\text { Significant only } \\
\text { precleaning }\end{array}$ & $\begin{array}{c}\text { 3M Clean-Trace ATP } \\
\text { System }\end{array}$ \\
\hline $\begin{array}{l}\text { Smith et al., } 2013 \\
\text { [24] }\end{array}$ & U.S. & Hospital & $\begin{array}{l}18 \text { samples pre- } \\
\text { cleaning in } 10 \\
\text { rooms }\end{array}$ & 250 & Significant & $\begin{array}{c}\text { 3M Clean-Trace ATP } \\
\text { System }\end{array}$ \\
\hline $\begin{array}{l}\text { Watanabe et al., } \\
2014 \text { [27] }\end{array}$ & Japan & $\begin{array}{l}\text { Three hospital of } \\
\text { different sizes }\end{array}$ & $\begin{array}{l}752 \text { samples post } \\
\text { cleaning }\end{array}$ & 127 & Poor $(r=0.287)$ & $\begin{array}{c}\text { 3M Clean-Trace ATP } \\
\text { System }\end{array}$ \\
\hline $\begin{array}{l}\text { Willis et al., } 2007 \\
\text { [15] }\end{array}$ & UK & Hospital & $\begin{array}{l}108 \text { samples post } \\
\text { cleaning }\end{array}$ & $\begin{array}{c}100 \text { (surfaces), } \\
300 \text { (floor) }\end{array}$ & Poor $(r=0.15)$ & Hygiena system \\
\hline $\begin{array}{l}\text { Zambrano et al., } \\
2014 \text { [28] }\end{array}$ & Chile & Teaching hospital & $\begin{array}{c}198 \text { samples pre and } \\
\text { post cleaning }\end{array}$ & Not reported & Not investigated & $\begin{array}{l}\text { Lightning MVPTM } \\
\text { (Arquimed) }\end{array}$ \\
\hline
\end{tabular}




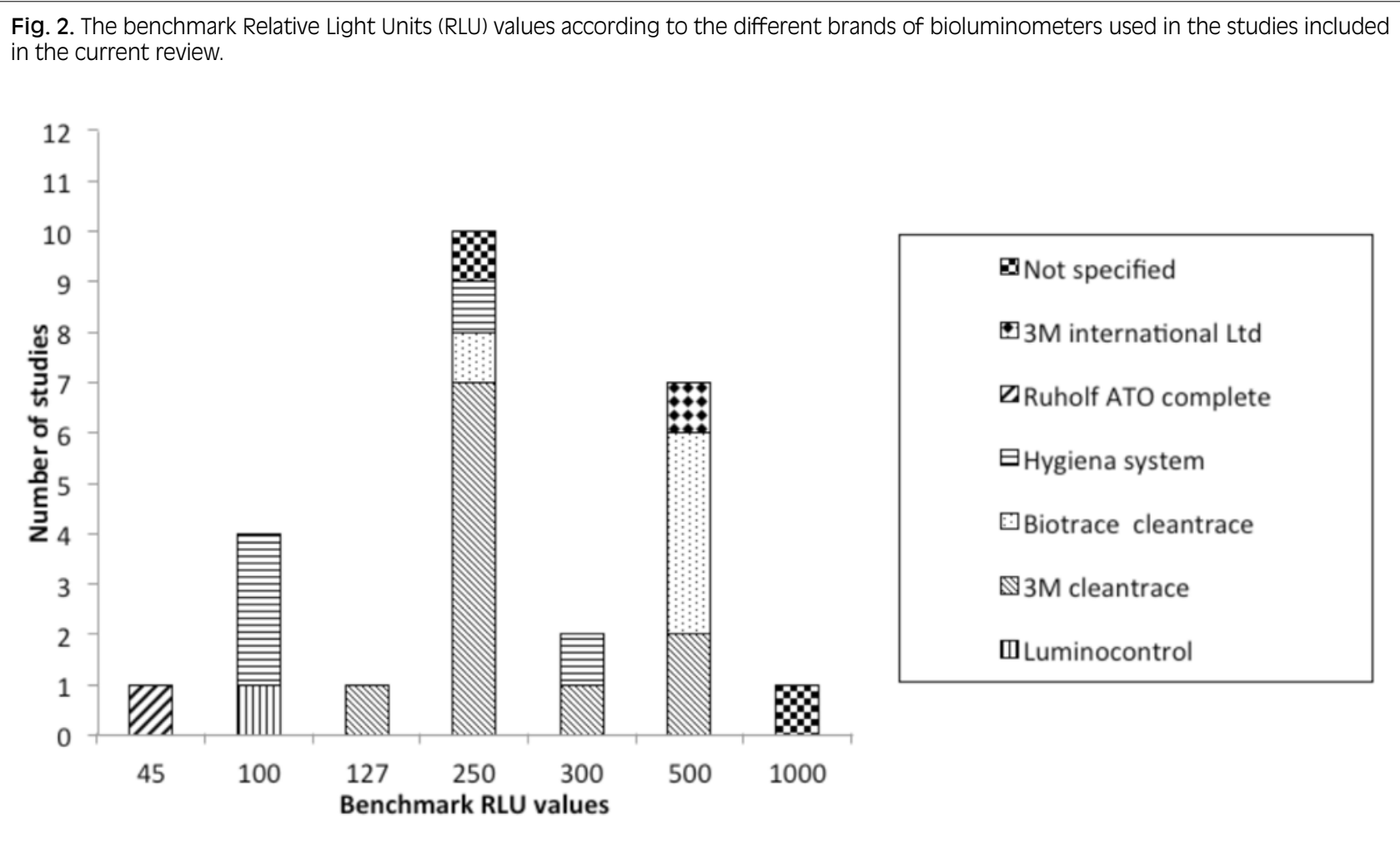

*In three studies $[22,26,28]$ other types of bioluminometers were used and the RLU benchmark values were not indicated

Fig. 3. The benchmark Relative Light Units (RLU) values according to geographical provenance of studies.

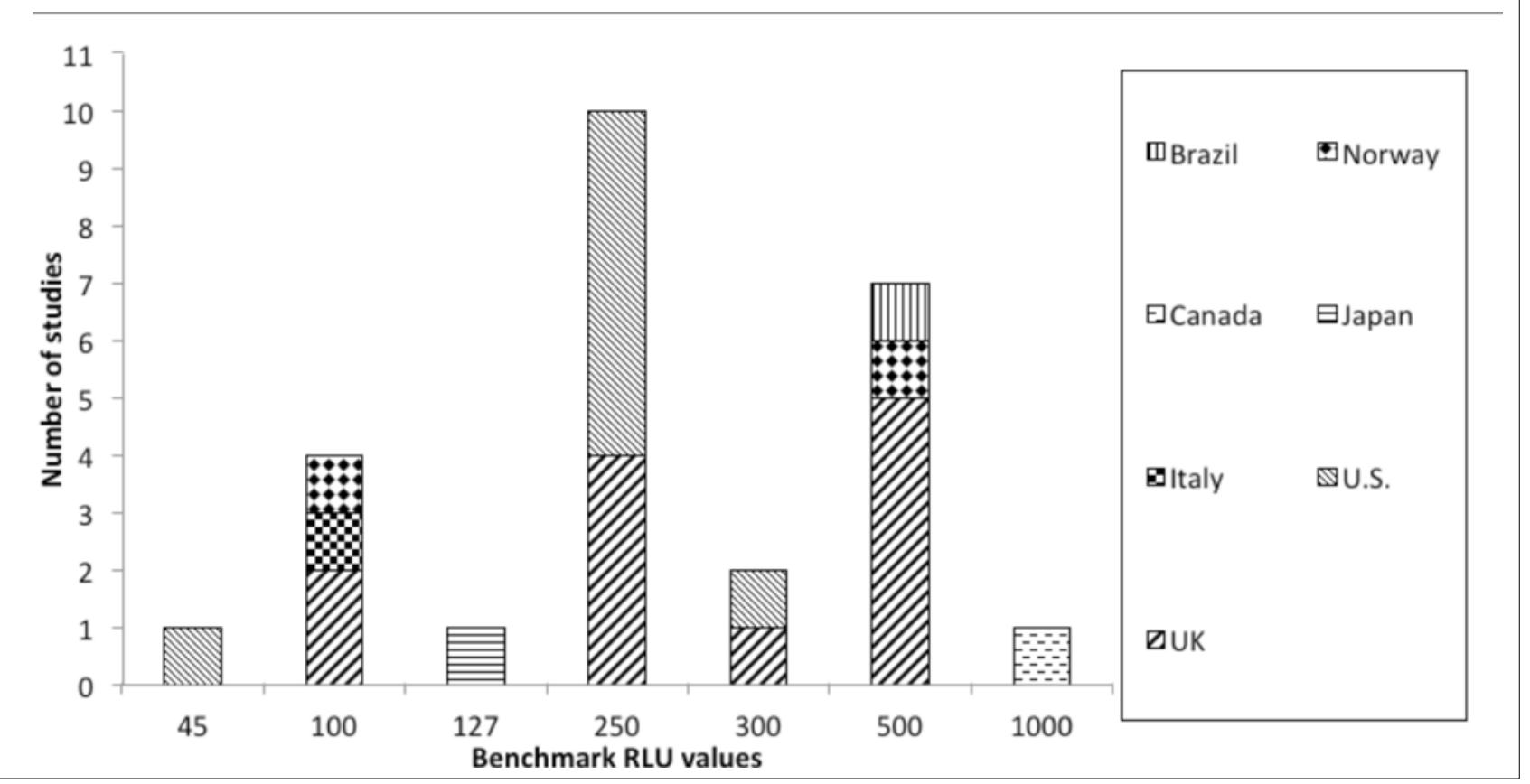

A large majority of studies was conducted in UK and in USA, probably because in these Countries there is a growing interest about environmental hospital hygiene and methods to assess it. Furthermore, it should be noted that among 14 studies investigating the correlation be- tween ATP bioluminescence and microbiological methods, 11 have found a significant correlation, although poor, or partial, for 5 papers. ATP bioluminescence would not seem to be a methodology very accurate in detecting bacteria. In addition, it provides a quantifica- 
tion of all organic material, including bacteria, but it also identifies others organic matters such as urine, milk and blood, which is a limiting aspect of the methods and is rather difficult to overcome [10].

Another limitation of this technique could be the residues of detergent or disinfectants on the surfaces [32], which may require rinsing of these surfaces before the use [33].

Despite of these considerations, some advantages of this technique can be listed, such as the possibility to provide real-time results (within 20 seconds of sampling), its simplicity of use (which makes possible the adoption of the method not only by trained healthcare staff), and the quantitative results. The latter allows comparisons between pre- and post-cleaning or between different surfaces.

Our study has a number of shortcoming that should be properly recognized. Despite the broad and systematic search, the main limitations of this study could be found in the selection of papers written only in English language and, therefore, in the possibility of having missed some relevant papers, which, considering the novelty of the technique, could be found, instead, in the "grey literature". On the other hand, it should be expected that the quality of the latter papers would be inferior to those present in the scholarly peer-reviewed indexed literature. Concerning the main implications of the current study, we can conclude that the use of this technique could produce better results after a proper validation/standardization. To achieve this aim a multi-phase approach should be followed: i) to clarify the methods of sanitizing or disinfecting performed on each surfaces before the controls made with the bioluminometer; ii) to select the most appropriate surfaces where the analysis have to be conducted (for example "high risk objects" such as toilet seats, basins, door handles); iii) to choose the bioluminometer among the different brands available; iv) to calibrate the instruments studying the correlation between CFU and RLU, identifying the best threshold value (higher sensitivity and specificity) [33] which discriminates between clean and dirt surfaces.

\section{Conclusions}

In conclusion, the ATP bioluminescence could be considered a practical, useful method to assess hospital hygiene, performing better than visual inspection (namely, Bacharach scale, bassoumeter, and glossmeter), if properly adopted, also being aware of its possible limits.

\section{Acknowledgements}

The authors thank Dr Nicola Bragazzi for his helpful suggestions.

The authors declare that there is no conflict of interest regarding the publication of this paper.

\section{Authors' contributions}

NN conceived the research. EC and GM researched and analyzed the study using for review and evaluated the results. EC, GM and DL performed the data quality control. EC, GM and PM wrote the manuscript. PM supervised the research. All Authors revised the manuscript and gave their contribution to improve the paper. All authors read and approved the final manuscript.

\section{References}

[1] Boyce JM. Environmental contamination makes an important contribution to hospital infection. J Hosp Infect 2007;65:50-4

[2] Weber DJ, Rutala WA. Understanding and preventing transmission of healthcare-associated pathogens due to the contaminated hospital environment. Infect Control Hosp Epidemiol 2013;34:449-52.

[3] Gordon L, Bruce N, Suh KN, Roth V. Evaluating and operationalizing an environmental auditing program: a pilot study. Am J Infect Control 2014;42:702-7.

[4] Messina G, Ceriale E, Lenzi D, Burgassi S, Azzolini E, Manzi P. Environmental contaminants in hospital settings and progress in disinfecting techniques. Biomed Res Int 2013;2013:429780.

[5] Liberati A, Altman DG, Tetzlaff J, Mulrow C, Gøtzsche PC, Ioannidis JP, Clarke M, Devereaux PJ, Kleijnen J, Moher D. The PRISMA statement for reporting systematic reviews and metaanalyses of studies that evaluate health care interventions: explanation and elaboration. PLoS Med 2009;6(7):e1000100.

[6] Ali S, Moore G, Wilson APR. Effect of surface coating and finish upon the cleanability of bed rails and the spread of Staphylococcus aureus. J Hosp Infect 2012;80:192-8.

[7] Anderson RE, Young V, Stewart M, Robertson C, Dancer SJ. Cleanliness audit of clinical surfaces and equipment: Who cleans what? J Hosp Infect 2011;78:178-81.

[8] Cooper RA, Griffith CJ, Malik RE, Obee P, Looker N. Monitoring the effectiveness of cleaning in four British hospitals. Am J Infect Control 2007;35:338-41.

[9] Griffith CJ, Cooper RA, Gilmore J, Davies C, Lewis M. An evaluation of hospital cleaning regimes and standards. J Hosp Infect 2000;45:19-28.

[10] Lewis T, Griffith C, Gallo M, Weinbren M. A modified ATP benchmark for evaluating the cleaning of some hospital environmental surfaces. J Hosp Infect 2008;69:156-63.

[11] Malik RE, Cooper RA, Griffith CJ. Use of audit tools to evaluate the efficacy of cleaning systems in hospitals. Am J Infect Control 2003;31:181-7.

[12] Moore G, Smyth D, Singleton J, Wilson P. The use of adenosine triphosphate bioluminescence to assess the efficacy of a modified cleaning program implemented within an intensive care setting. Am J Infect Control 2010;38:617-22.

[13] Mulvey D, Redding P, Robertson C, Woodall C, Kingsmore P, Bedwell D, Dancer SJ. Finding a benchmark for monitoring hospital cleanliness. J Hosp Infect 2011;77:25-30.

[14] Sherlock O, O'Connell N, Creamer E, Humphreys H. Is it really clean? An evaluation of the efficacy of four methods for determining hospital cleanliness. J Hosp Infect 2009;72:140-6.

[15] Willis C, Morley R, Westbury J, Greenwood M, Pallett A. Evaluation of ATP bioluminescence swabbing as a monitoring and training tool for effective hospital cleaning. Br J Infect Contr 2007;8:17-21.

[16] Amin SR, Folkert CM, Erie JC. Assessing the effectiveness of surface cleaning methods in intravitreal injection procedure rooms. Ophthalmolog. 2014;121:276-82.

[17] Boyce JM, Havill NL, Dumigan DG, Golebiewski M, Balogun 
O, Rizvani R. Monitoring the effectiveness of hospital cleaning practices by use of an adenosine triphosphate bioluminescence assay. Infect Control Hosp Epidemiol 2009;30:678-84.

[18] Boyce JM, Havill NL, Havill HL, Mangione E, Dumigan DG, Moore BA. Comparison of fluorescent marker systems with 2 quantitative methods of assessing terminal cleaning practices. Infect Control Hosp Epidemiol 2011;32:1187-93.

[19] Branch-Elliman W, Robillard E, McCarthy Jr G, Gupta K. Direct feedback with the ATP luminometer as a process improvement tool for terminal cleaning of patient rooms. Am J Infect Control 2014;42:195-7.

[20] Gold KM, Hitchins VM. Cleaning assessment of disinfectant cleaning wipes on an external surface of a medical device contaminated with artificial blood or Streptococcus pneumoniae. Am J Infect Control 2013;41:901-7.

[21] Havill NL, Havill HL, Mangione E, Dumigan DG, Boyce JM Cleanliness of portable medical equipment disinfected by nursing staff. Am J Infect Control 2011;39:602-4.

[22] Luick L, Thompson PA, Loock MH, Vetter SL, Cook J, Guerrero DM. Diagnostic assessment of different environmental cleaning monitoring methods. Am J Infect Control 2013;41:751-2.

[23] Smith PW, Gibbs S, Sayles H, Hewlett A, Rupp ME, Iwen PC Observations on hospital room contamination testing. Healthcare Infection 2013;18:10-3

[24] Smith PW, Sayles H, Hewlett A, Cavalieri J, Gibbs SG, Rupp ME. A study of three methods for assessment of hospital environmental cleaning. Healthcare Infection 2013;18:80-5.

[25] Amodio E, Cannova L, Villafrate MR, Merendino AM, Aprea L, Calamusa G. Analytical performance issues: comparison of ATP bioluminescence and aerobic bacterial count for evaluating surface cleanliness in an Italian hospital. J Occup Environ Hyg 2014;11:D23-D7.
[26] Aycicek H, Oguz U, Karci K. Comparison of results of ATP bioluminescence and traditional hygiene swabbing methods for the determination of surface cleanliness at a hospital kitchen. Int J Hyg Environ Health 2006;209:203-6.

[27] Watanabe R, Shimoda T, Yano R, Hayashi Y, Nakamura S, Matsuo J, Yamaguchi H. Visualization of hospital cleanliness in three Japanese hospitals with a tendency toward long-term care. BMC Res Notes 2014;7.

[28] Zambrano AA, Jones A, Otero P, Ajenjo MC, Labarca JA. Assessment of hospital daily cleaning practices using ATP bioluminescence in a developing country. Braz J Infect Dis 2014; 18:675-7.

[29] Andersen BM, Rasch M, Kvist J, Tollefsen T, Lukkassen R, Sandvik L, Welo A. Floor cleaning: effect on bacteria and organic materials in hospital rooms. J Hosp Infect 2009;71:57-65.

[30] Gillespie E, Wilson J, Lovegrove A, Scott C, Abernethy M, Kotsanas D, Stuart RL. Environment cleaning without chemicals in clinical settings. Am J Infect Control 2013;41:461-3.

[31] Ferreira AM, de Andrade D, Rigotti MA, Ferreira MVF. Condition of cleanliness of surfaces close to patients in an intensive care unit. Condições de limpeza de superfícies próximas ao paciente, em uma unidade de terapia intensive. Rev. Latino-Am. Enfermagem 2011;19:557-64.

[32] Boyce JM, Havill NL, Lipka A, Havill H, Rizvani R. Variations in hospital daily cleaning practices. Infect Control Hosp Epidemiol 2010;31:99-101.

[33] Manzi P, Barbini P, Ricci N,Fidone G, Pompili O, Donatelli E. Validazione del processo di pulizia in aree critiche mediante bioluminometria. L'Ospedale 2012;2:64-71.
Received on December 18, 2016. Accepted on February 17, 2017

Correspondence: Gabriele Messina, Research Professor of Public Health, University of Siena, Department of Molecular and Developmental Medicine, via A. Moro 2, Siena, 53100 Italy - Tel.+39 0577234139 - Fax +39 0577234090 - E-mail: gabriele.messina@ unisi.it 